\title{
Protein Content and Amino Acid Balance of Yams ${ }^{1,2}$
}

\author{
F. W. Martin ${ }^{3}$ and A. E. Thompson ${ }^{4}$
}

\section{INTRODUCTION}

Yams (Dioscorea species) are widely distributed throughout the Tropics where they play a prominent role in the human diet. As carbohydrate staples, they are usually preferred over cheaper substitutes (cassava and cocoyams). Yams have achieved a prominent and probably permanent status in the diet particularly in West Africa. About half the world's annual tonnage of yams ( 25 million) is produced and consumed in that region alone.

Yams from a nutritional standpoint chiefly supply carbohydrates (starch) to the diet. Starch content ranges from 20 to 40 percent depending on species, variety and maturity of tuber. The starch granules tend to be large in some species (D. alata L., D. rotundata Poir.), but small and comparable to those of cassava in D. esculenta (Lour.) Burk. Sugars, principally sucrose and glucose, are easily detected but are not prominent components of most yams. Among minor constituents, ascorbic acid concentration is sufficient to play a role in the diet; smaller quantities of $B$ vitamins are also found. The nutritional value of yams has been discussed by Coursey (2).

The protein content of yams may be of considerable significance where used in a staple food. Protein deficiency (kwashiorkor) is associated with yam consumption, but is usually not as severe as that associated with diets based on cassava. The sparse literature suggests this is due to a higher protein content in yams than in other competing starch-bearing staples.

Amino acid analyses of yams have been reported in the literature in a few instances. Dioscorea alata and D. rotundata are reported by Busson (1) to contain very high quantities of phenylalanine but deficiencies of cystine, tryptophan and valine, as compared to whole egg. Data from FAO (3) suggest that Dioscorea spp. are deficient in sulphur-containing amino acids, particularly cystine. Isoleucine is listed in one instance as a limiting amino acid.

1 Manuscript submitted to Editorial Board July 7, 1972.

${ }^{2}$ Research supported in part by contract with U. S. Agency for International Development, and in part by Funds for Tropical Agriculture, University of Illinois, Urbana.

Plant Geneticist, Federal Experiment Station, Agricultural Research Service, U. S. Department of Agriculture, Mayagüez, P.R.

- Department of Horticulture, University of Arizona, Tucson, Arizona. 


\section{MATERIALS AND METHODS}

Thirty-eight of the yam varieties previously tested for protein content (5) were also studied for amino acid balance. The yams were grown together under optimum conditions. The samples were selected in a manner avoiding experimental bias. These were dried in a forced draft oven at $58^{\circ} \mathrm{C}$. Samples of $500 \mathrm{mg}$. were treated with $6 \mathrm{~N} \mathrm{HCl}$, flushed with $\mathrm{N}$ and evacuated several times to eliminate traces of air, and hydrolized 4 hours

TABLE 1.-A summary of the relative (percent of total amino acids represented by amino acid in question) amino acid contents of yam proteins as compared

to that of egg (dry weight basis)

\begin{tabular}{|c|c|c|c|c|c|c|c|c|c|c|}
\hline \multirow{2}{*}{ Amino acid } & \multicolumn{2}{|c|}{ D. alata } & \multicolumn{2}{|c|}{ D. esculenia } & \multicolumn{2}{|c|}{ D. bulbifera } & \multicolumn{2}{|c|}{ D. rotundala } & \multirow{2}{*}{ D. trifida } & \multirow{2}{*}{ Egg } \\
\hline & Low & High & Low & High & Low & High & Low & High & & \\
\hline Leucine & 7.42 & 8.69 & 6.35 & 8.77 & 8.84 & 9.86 & 7.53 & $7.69 \mid$ & 8.64 & 8.54 \\
\hline Isoleucine & 3.64 & 5.15 & 3.86 & 4.47 & 4.73 & 5.20 & 3.79 & 3.81 & 4.41 & 6.09 \\
\hline Lysine & 4.74 & 5.68 & 2.60 & 3.30 & 3.05 & 3.60 & 2.75 & 3.21 & 3.09 & 6.76 \\
\hline Methionine & 1.48 & 1.90 & 1.36 & 1.65 & 1.54 & 1.61 & \begin{tabular}{|l|}
1.67 \\
\end{tabular} & $|1.86|$ & 1.27 & 3.25 \\
\hline Cystine & .32 & 1.16 & .50 & .90 & .50 & 1.40 & .84 & 1.38 & 1.10 & 2.25 \\
\hline Phenylalanine & 5.53 & 6.76 & 4.17 & 6.01 & 5.53 & 6.40 & 6.07 & 6.30 & 5.16 & 5.55 \\
\hline Tyrosine & 2.12 & 3.52 & 2.60 & 3.30 & 3.05 & 3.60 & 2.75 & 3.21 & 3.09 & 4.03 \\
\hline Threonine & 3.54 & 4.44 & 3.94 & 4.34 & 4.36 & 5.01 & 3.95 & 4.26 & 5.03 & 4.96 \\
\hline Valine & 4.13 & 5.36 & 4.08 & 5.15 & 5.53 & 6.02 & 4.61 & 4.65 & 5.05 & 6.63 \\
\hline Arginine & 7.61 & 15.82 & 19.97 & 23.37 & 4.60 & 7.45 & 9.63 & 9.90 & 12.23 & 5.90 \\
\hline Histidine & 1.77 & 4.02 & 2.41 & 3.26 & 2.79 & 3.06 & 3.17 & 3.55 & 2.98 & 2.35 \\
\hline Alanine & 4.14 & 6.35 & 4.10 & 6.60 & 6.12 & 8.17 & 5.35 & 5.54 & 5.37 & 5.74 \\
\hline Aspartic Acid & 11.76 & 13.93 & 9.38 & $3|13.62|$ & 12.69 & 14.13 & 12.79 & $|12.79|$ & 12.31 & 9.32 \\
\hline Glutamic acid & 14.53 & 16.31 & 11.60 & 13.85 & 12.83 & 16.30 & 15.99 & 16.63 & 13.85 & 12.34 \\
\hline Glycine & 3.21 & 4.43 & 3.86 & 4.47 & 4.73 & 5.20 & 3.79 & 3.81 & 4.41 & 3.21 \\
\hline Proline & 4.33 & 4.95 & 4.61 & $1 \mid 5.15$ & 4.17 & 4.65 & 3.97 & 4.17 & 4.21 & 4.03 \\
\hline Serine & 6.18 & 8.99 & 5.71 & 19.33 & 7.23 & 9.04 & 6.16 & 7.62 & 7.10 & 7.41 \\
\hline Varieties evaluated & 2 & 6 & & 6 & & 3 & & 2 & 1 & \\
\hline
\end{tabular}

at $145^{\circ} \mathrm{C}$ under vacuum (6). After hydrolysis, the solution was filtered through glass fiber filter paper. An aliquot of the sample solution was then used to determine amino acid content by gas-liquid column chromatography (4). Tryptophan is destroyed by acid hydrolysis and not measured.

\section{RESULTS AND DISCUSSION}

The levels of essential, "semi-essential" and non-essential amino acids are summarized for the five species tested in table 1, as a percentage of the total amino acids recovered. The quality of the protein in this form can be compared directly to that of whole egg, a common reference protein. 
The table indicates that yams contain only one amino acid present in proportionally larger amounts in yam than in egg protein, arginine. It occurs in abundance in all yam species, except some varieties of $D$. bulbifera L. Yam protein contents are somewhat low in the essential amino acid lysine, except in $D$. alata, in which all varieties apparently contain relatively high amounts. Yam protein, however, is about as adequate as that of whole egg for the majority of the essential and non-essential amino acids. Aspartic acid content is especially high. With respect to the sulphurcontaining amino acids, yam protein on an average contains 49 percent of the methionine, but only 17 percent of the cystine (36 percent of total sulphur-containing amino acids) as compared to protein of whole egg. These relationships are shown in figure 1. Thus, the sulphur-containing amino acids, especially cystine, are the limiting amino acids of yam. The data in table 1, which consists of ranges within species, suggest some varietal differences at least as great as those among the species themselves.

Methionine, cystine, and total sulphur-containing amino acids are given in table 2 for the 38 yam cultivars tested, together with total protein (5) and total amino acids recovered. Total amino acids recovered after hydrolysis was always somewhat lower than protein content as estimated from total $\mathrm{N}$ (Kjeldahl) determinations. However, varieties retained approximately the same rank with respect to relative content. Varieties that were rich in total amino acids (Florido, Cuello Largo, and Brazo Fuerte, for example) were also richest in sulphur-containing amino acids.

Total contents of methionine and cystine were usually too low to record as more than one significant figure. Nevertheless, some yams obviously were richer in these two limiting sulphur-containing amino acids than others. The relative rather than absolute content is probably more useful (table 2, columns 6 and 7) for direct comparisons then can be made with egg (footnote, table 2).

In relation to methionine, protein of Oriental, Smooth Statia, Feo, Gordito, Cuello Largo, Sweet, Guinea Blanco and Akandou contain the largest quantities of methionine, but even the best in this respect (Sweet) contains only 45 percent more methionine than the poorest (Mapuey Largo). In relation to cystine, varietal variation is greater; varieties with highest relative cystine content of their protein and their relative content as compared to whole egg protein are: Seal Top (26\%), Feo (24\%), Brazo Fuerte (30\%), Cuello Largo (25\%), Sweet (23\%), Angled Gunda (31\%), Guinea Blanco (30\%), and Mapuey Largo (25\%). The variety with highest relative cystine content (Angled Gunda) contained 440-percent more cystine than that with the lowest relative cystine content (Macoris). Relative methionine content is not correlated with total protein $(r=0.03)$ but cystine content is partially correlated $(r=0.48)$. Methionine and cystine 


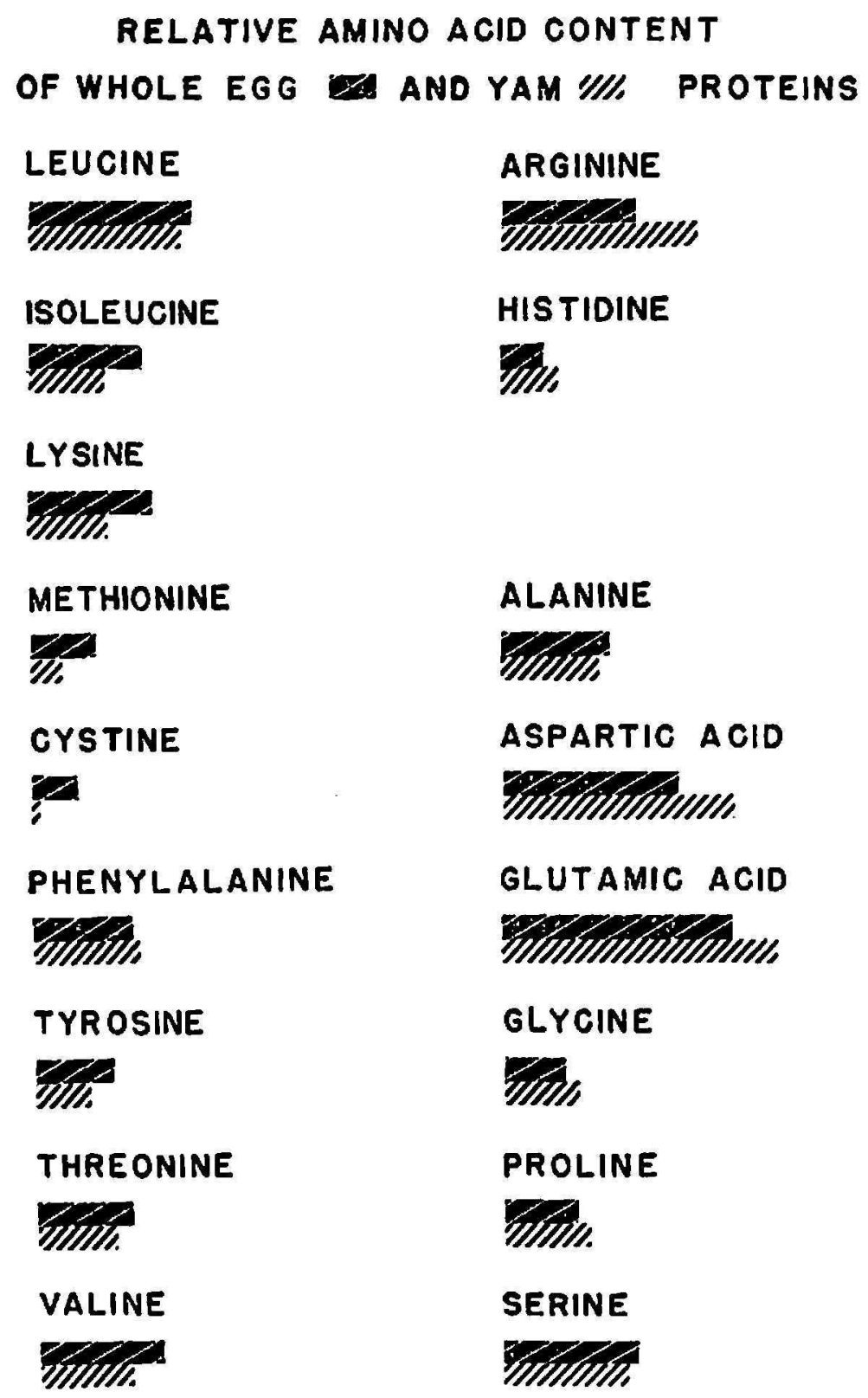

FIG. 1.-Bar graphs comparing the relative amino acid contents of yam protein (fine stripes) to that of egg (thick stripes).

relative contents are only partially correlated $(r=0.33)$. The measurement of total sulphur-containing amino acids may be more important, however, than measurement of either methionine or cystine.

Because of the difficulty in obtaining measurements of cystine and methionine, and the possibility of oxidation during preparation and measurement, these measurements must be interpreted with caution. Future selections must be replicated, and the value of the protein must be checked through biological tests for reliability.

The implications of these findings are that diets heavily dependent on yams may possibly reach minimum levels of protein necessary for health. 
TABLE 2.-Crude protein contents, tolal amino acid, and total and relative amounts of limiting and sulphur-bearing amino acids (dry weight basis)

\begin{tabular}{|c|c|c|c|c|c|c|c|}
\hline \multirow{2}{*}{ Cultivar } & \multirow{2}{*}{$\begin{array}{c}\text { Total } \\
\text { protein }\end{array}$} & \multirow{2}{*}{$\begin{array}{c}\text { Total } \\
\text { amino } \\
\text { acids }\end{array}$} & \multicolumn{3}{|c|}{ Total } & \multicolumn{2}{|c|}{ Relative } \\
\hline & & & $\begin{array}{l}\text { Methi- } \\
\text { onine }\end{array}$ & Cystine & S. con. 1 & $\begin{array}{l}\text { Methi- } \\
\text { onine }\end{array}$ & Cystine \\
\hline & Percent & G./100 g. & G. $/ 100 \mathrm{~g}$. & G. $/ 100 \mathrm{~g}$. & G./100 g. & Percent & Percent \\
\hline \multicolumn{8}{|l|}{ Dioscorea alata } \\
\hline Morado & 8.04 & 5.99 & 0.09 & 0.02 & 0.11 & 1.48 & 0.28 \\
\hline Ashmore & 7.21 & 5.60 & .09 & .01 & .10 & 1.57 & .16 \\
\hline Vino blanco & 8.06 & 6.50 & .09 & .02 & .11 & 1.45 & .34 \\
\hline Purple Lisbon & 7.66 & 6.16 & .09 & .02 & .10 & 1.50 & .36 \\
\hline Macoris & 7.68 & 6.08 & .09 & .03 & .12 & 1.54 & .15 \\
\hline Barbados & 8.12 & 6.36 & .09 & .03 & .12 & 1.47 & .41 \\
\hline Florido & 10.47 & 8.22 & .13 & .04 & .17 & 1.58 & .43 \\
\hline Yellow Lisbon & 7.91 & 5.99 & .10 & .03 & .13 & 1.60 & .42 \\
\hline Bottleneck Lisbon & 7.25 & 5.65 & .09 & .02 & .11 & 1.54 & .40 \\
\hline Oriental & 7.72 & 6.32 & .11 & .02 & .13 & 1.72 & .27 \\
\hline Seal Top & 7.84 & 5.73 & .09 & .03 & .12 & 1.57 & .58 \\
\hline Smooth Statia & 6.56 & 5.23 & .09 & .02 & .11 & 1.67 & .29 \\
\hline Farm Lisbon & 8.25 & 6.43 & .10 & .02 & .12 & 1.51 & .36 \\
\hline De Palo & 8.88 & 7.34 & .12 & .02 & .14 & 1.63 & .27 \\
\hline Feo & 8.16 & 6.68 & .12 & .04 & .16 & 1.86 & .54 \\
\hline Pyramid & 9.41 & 6.03 & .10 & .03 & .13 & 1.61 & .48 \\
\hline Prolific & 9.44 & 7.38 & .11 & .03 & .14 & 1.50 & .35 \\
\hline Corazón & 9.16 & 6.03 & .09 & .03 & .12 & 1.55 & .43 \\
\hline Espada & 10.82 & 7.11 & .11 & .01 & .12 & 1.59 & .17 \\
\hline Gordito & 8.47 & 6.61 & .11 & .02 & .13 & 1.67 & .29 \\
\hline Cuello Largo & 11.22 & 8.13 & .14 & .05 & .19 & 1.70 & .57 \\
\hline Brazo Fuerte & 6.28 & 4.69 & .16 & .07 & .23 & 1.57 & .68 \\
\hline Hawaii Branching & 8.28 & 6.07 & .09 & .02 & .11 & 1.56 & .28 \\
\hline Forastero & 7.25 & 5.64 & .09 & .01 & .10 & 1.60 & .17 \\
\hline Sweet & 6.84 & 4.81 & .09 & .03 & .12 & 1.90 & .53 \\
\hline Hunte & 9.22 & 6.96 & .11 & .01 & .12 & 1.62 & .21 \\
\hline \multicolumn{8}{|l|}{ D. esculenta } \\
\hline Papa & 8.19 & 5.61 & .08 & .02 & .10 & 1.36 & .34 \\
\hline Pana & 9.31 & 7.33 & .12 & .02 & .14 & 1.60 & .31 \\
\hline Trinulenta & 8.94 & 6.67 & .09 & .02 & .11 & 1.32 & .25 \\
\hline Fasciculata & 13.41 & 9.59 & .15 & .03 & .18 & 1.55 & .36 \\
\hline Spindle & 8.82 & 7.18 & .12 & .03 & .15 & 1.64 & .45 \\
\hline Assam & 7.84 & 6.32 & .10 & .02 & .12 & 1.65 & .25 \\
\hline \multicolumn{8}{|l|}{ D. bulbifera } \\
\hline Round Gunda & 9.90 & 8.88 & .14 & .02 & .16 & 1.54 & .25 \\
\hline Angled Gunda & 11.06 & 10.03 & .16 & .07 & .23 & 1.61 & .70 \\
\hline Sativa & 10.94 & 10.17 & .16 & .05 & .21 & 1.55 & .52 \\
\hline \multicolumn{8}{|l|}{ D. rotundata } \\
\hline Guinea Blanco & 8.06 & 6.74 & .13 & .05 & .18 & 1.86 & .69 \\
\hline Akandou & 7.28 & 5.57 & .09 & .02 & .11 & 1.67 & .42 \\
\hline \multicolumn{8}{|l|}{ D. trifida } \\
\hline Mapuey Largo & 7.38 & 5.74 & .07 & .03 & .10 & 1.27 & .55 \\
\hline Whole egg & & & & & & 3.25 & 2.25 \\
\hline
\end{tabular}

${ }^{1}$ S. con. = sulphur-containing amino acids. 
However, the protein will be deficient in sulphur-containing amino acids, especially cystine. These amino acids should be obtained from other sources to balance the diet.

The fact that cystine content varies widely among yam cultivars suggests the possibility that superior varieties can be selected, or possibly bred less deficient in this essential amino acid. The use of high cystine carrying varieties as food in substitution for cystine-deficient varieties would help fill the nutritional gap where these tubers are used as staples.

The situation pertaining to tryptophan remains to be determined in yam.

\section{SUMMARY}

The total protein of 38 yam (Dioscorea) cultivars, as tested by Kjeldahl methods, and their amino acid composition, determined by high temperature hydrolysis and GLC chromatography, are reported. Species and varieties differed in total protein and total amino acid contents. Proteins of four species, but not $D$. alata, were somewhat low in lysine. Proteins of all species were deficient in sulphur-containing amino acids, methionine, and especially cystine. Varietal differences, however, suggest that cultivars can be selected with more balanced protein.

\section{RESUMEN}

Se informaron los contenidos proteínicos totales de 38 variedades de ñame (Dioscorea) determinados mediante métodos $\mathrm{Kjeldahl} \mathrm{y} \mathrm{su} \mathrm{composición} \mathrm{respecto} \mathrm{a} \mathrm{los}$ aminoácidos, determinada por hidrólisis a temperaturas altas y cromatografía de gas líquido. Se encontraron diferencias entre las especies y variedades entre sí en cuanto al contenido total de proteína y de aminoácidos. Cuatro de las especies, excluyendo D. alala, revelaron ser algo deficientes en lisina. Todas las especies revelaron deficiencias en aminoácidos que contienen azufre, metionina y especialmente cistina. No obstante, las deferencias entre las variedades sugieren que es posible seleccionar algunas que contengan más proteína y un mejor balance de los aminoácidos.

\section{LITERATURE CITED}

1. Busson, F., Plantes Alimentaires de L'Ouest Africain, Leconte, Marseille, France, 1965.

2. Coursey, D. G., Yams, Longmans, Green and Co., London, England, 1967.

3. Food and Agriculture Organization of the United Nations, Amino Acid Content of Foods and Biological Data on Proteins, FAO Nutritional Studies No. 24, 1970.

4. Gehrke, C. W., Kuo, K., and Zumwalt, R. M., Complete gas-liquid chromatography of the twenty protein amino acids, J. Chromatogr. 57: 209-18, 1971.

5. Martin, F. W. and Thompson, A. E., Crude protein content of yams, Hort. Sci. 6: 545-46, 1971.

6. Roach, D. and Gehrke, C. W., The hydrolysis of proteins, J. Chromatogr. 53: 393409, 1970. 